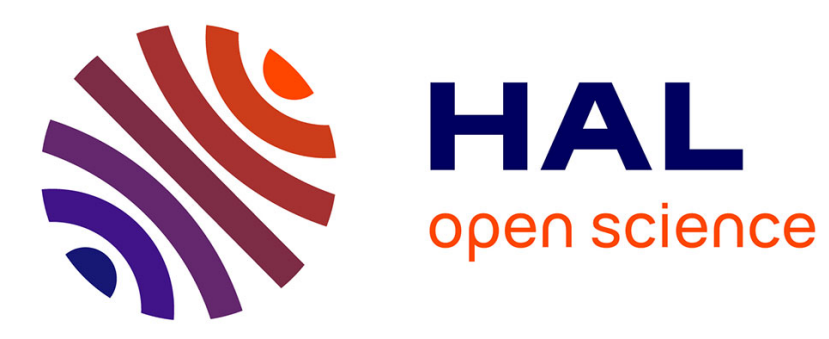

\title{
Production of hydrogen via conversion of hydrocarbons using a microwave plasma
}

Mariusz Jasiński, Miroslaw Dors, Helena Nowakowska, Gerietta V Nichipor, Jerzy Mizeraczyk

\section{- To cite this version:}

Mariusz Jasiński, Miroslaw Dors, Helena Nowakowska, Gerietta V Nichipor, Jerzy Mizeraczyk. Production of hydrogen via conversion of hydrocarbons using a microwave plasma. Journal of Physics D: Applied Physics, 2011, 44 (19), pp.194002. 10.1088/0022-3727/44/19/194002 . hal-00615135

\section{HAL Id: hal-00615135 \\ https://hal.science/hal-00615135}

Submitted on 18 Aug 2011

HAL is a multi-disciplinary open access archive for the deposit and dissemination of scientific research documents, whether they are published or not. The documents may come from teaching and research institutions in France or abroad, or from public or private research centers.
L'archive ouverte pluridisciplinaire HAL, est destinée au dépôt et à la diffusion de documents scientifiques de niveau recherche, publiés ou non, émanant des établissements d'enseignement et de recherche français ou étrangers, des laboratoires publics ou privés. 


\title{
PRODUCTION OF HYDROGEN VIA CONVERSION OF HYDROCARBONS USING MICROWAVE PLASMA
}

\author{
Mariusz Jasiński ${ }^{1}$, Mirosław Dors ${ }^{1}$, Helena Nowakowska ${ }^{1}$, \\ Gerietta V. Nichipor ${ }^{3}$, Jerzy Mizeraczyk ${ }^{1,2}$
}

${ }^{1}$ Centre for Plasma and Laser Engineering, The Szewalski Institute of Fluid-Flow Machinery, Polish Academy of Sciences, Fiszera 14, 80-952 Gdańsk, Poland, e-mail: mj@imp.gda.pl

${ }^{2}$ Department of Marine Electronics, Gdynia Maritime University, Morska 83, 81-225 Gdynia, Poland

${ }^{3}$ Joint Institute of Power and Nuclear Research, Academy of Sciences of Belarus, Minsk, Sosny 220109 Belarus

Keywords: microwave plasma, hydrogen production, conversion of hydrocarbons

\begin{abstract}
In this paper, results of hydrogen production from hydrocarbons in the atmospheric pressure microwave plasma are presented. As sources of hydrogen, both methane $\mathrm{CH}_{4}$ and tetrafluoroethane $\mathrm{C}_{2} \mathrm{H}_{2} \mathrm{~F}_{4}$ were tested. A new waveguide-based nozzleless cylindertype microwave plasma source was used to convert hydrocarbons into hydrogen. The processed gaseous hydrocarbons were introduced to the plasma by four gas ducts which
\end{abstract}


formed a swirl flow in the plasma reactor. The absorbed microwave power was up to $5 \mathrm{~kW}$. The gas flow rate was up to $2121 \mathrm{~min}^{-1}$. The hydrogen mass yield rate and the corresponding energetic hydrogen mass yield were up to $866 \mathrm{~g}\left[\mathrm{H}_{2}\right] \mathrm{h}^{-1}$ and $577 \mathrm{~g}\left[\mathrm{H}_{2}\right]$ per kWh of microwave energy absorbed by the plasma, respectively. These parameters are better than our previous results when nitrogen was used as a swirl gas and much better than those typical for other plasma methods of hydrogen production (electron beam, gliding arc, plasmatron).

\section{Introduction}

Recently hydrogen has gained in importance as fuel in fuel cell applications, combustion engines or gas turbines with the goal to achieve more efficient exploitation of energy sources and to reduce noxious emissions. The main substrate for hydrogen production is methane from the natural gas. Methane or natural gas reforming is widely used in industry to obtain hydrogen or synthesis gas $\left(\mathrm{H}_{2}+\mathrm{CO}\right)$, which are utilized in industry, for example as source materials for the production of raw chemicals (e.g. methanol and ammonia), as well as hydrogenation agents in oil refinery and reducing gases in steel industry [1-3].

Usual reforming of methane is carried out thermally with steam and oxygen where oxidation of methane takes place to provide reaction heat because the methane reforming reaction using steam is endothermic. The main reaction in the steam reforming of methane is the oxidation with steam, yielding a mixture of hydrogen and carbon monoxide $[1,3]$ : 


$$
\mathrm{CH}_{4}+\mathrm{H}_{2} \mathrm{O} \leftrightarrow \mathrm{CO}+3 \mathrm{H}_{2}, \Delta \mathrm{H}_{298}=206 \mathrm{~kJ} \mathrm{~mol}^{-1}
$$

Since that process is highly endothermic, to decrease activation energy, it requires catalyst, which is usually $\mathrm{Ni} / \mathrm{Al}_{2} \mathrm{O}_{3}$ working at temperature $1100-1150 \mathrm{~K}$. Hence the reforming system is sensible to impurities in substrates which deactivates catalysts $[2$, 3].

Conventional technologies of hydrogen production, i.e. coal gasification, hydrocarbon reforming and water electrolysis, are too expensive or not applicable for specific applications (e.g. for fuel cells) due to technical reasons. Thus, new methods are under development, like water photolysis, biological and plasma methods [4-7].

One of attracting methods for conversion hydrocarbons to produce hydrogen is the use of plasmas $[1-3,5-23]$. The plasma contains reactive radicals, ions and highenergetic electrons. High reactivity shown by these species enhances the chemical reaction rates whereby expensive and impurity vulnerable catalysts can be avoided. These advantages as well as its high energy density ensure the compactness of the plasma reformer. Besides, the plasma system can be adapted for reforming various hydrocarbons, like natural gas, gasoline, heavy oils and biofuels. Fast response time can be also achieved because the plasma is operated by electricity. When steam is used as the plasma supporting gas, reductive and oxidative radicals such as $\mathrm{H}, \mathrm{OH}$, and $\mathrm{O}$ are produced in the plasma, enabling the plasma to be effective for reforming different hydrocarbons.

Refrigerants based on fluorinated hydrocarbons may be another source of hydrogen. They have been used for many years in air-conditioned systems. Formerly, chlorofluoromethanes (CFCs) with different number of chlorine and fluorine atoms were used in these systems. Unfortunately, these CFCs are potential ozone depleting 
substances (ODSs). The use of CFCs has been prohibited by the Montreal Protocol since 1987. CFCs used as refrigerants have been replaced by hydrocarbons consisting of carbon, hydrogen and fluorine atoms, i.e. having no chlorine atoms. These chemicals, the so-called HFCs, are considered to be less harmful to the ozone layer. However, it is already foreseen that in the near future also HFCs will be out of use due to their particularly high global warming potential. Thus, efficient methods of destruction of the stored refrigerants, which have been used before, as well as those currently emitted to the atmosphere are in great demand. Since HFCs have hydrogen atoms in their structures, their destruction may be combined with hydrogen production.

Recently developed microwave plasma sources (MPSs) operated at atmospheric pressure $[11,12,22-31]$ seem to have a high potential for hydrogen production via hydrocarbon conversion. The microwave plasma at atmospheric pressure is one of the plasma techniques providing the electron temperature of $4000-10000 \mathrm{~K}$, and the heavy particle temperature of 2000-6000 K [26-31].

Our previous investigations in methane conversion to hydrogen [23] were carried out using methane (17.5-175 $\left.1 \mathrm{~min}^{-1}\right)$ and nitrogen swirl (50-100 $\left.1 \mathrm{~min}^{-1}\right)$ at relatively high absorbed microwave powers $(3000-5000 \mathrm{~W})$. The best conditions corresponded to the absorbed microwave power of $3000 \mathrm{~W}$ and methane flow rate of $1751 \mathrm{~min}^{-1}$, where the hydrogen mass yield rate and the corresponding energetic hydrogen mass yield were $222 \mathrm{~g}\left[\mathrm{H}_{2}\right] \mathrm{h}^{-1}$ and $74 \mathrm{~g}\left[\mathrm{H}_{2}\right]$ per $\mathrm{kWh}$ of microwave energy absorbed by the plasma. Since the hydrogen production presented in [23] was carried out in the presence of nitrogen without any oxygen carriers, the main chemical reaction producing hydrogen was methane pyrolysis.

Presence of nitrogen as well as methane conversion by-products, i.e. acetylene 
and unconverted methane, necessitate to separate hydrogen from other gaseous components using a gas separator unit. In order to avoid or to facilitate separation process, when high hydrogen purity is not required, we propose to use hydrocarbon as the only gas entering the plasma generator. Results of methane $\mathrm{CH}_{4}$ and tetrafluoroethane $\mathrm{C}_{2} \mathrm{H}_{2} \mathrm{~F}_{4}$ (HFC-134a) conversion to hydrogen without any other gaseous admixture are presented in this paper.

\section{Experimental setup}

The main parts of the experimental setup used in this investigation were: a microwave generator (magnetron), microwave plasma source (MPS), microwave supplying and measuring system, and gas supplying system (Figure 1). The microwave power $(2.45 \mathrm{GHz}, 6 \mathrm{~kW})$ was supplied from the magnetron to the MPS via a rectangular waveguide (WR-430) having a reduced-height section.

The absorbed microwave power $\mathrm{P}_{\mathrm{A}}(0.6-5 \mathrm{~kW})$, i.e. microwave power delivered to the discharge was calculated as $\mathrm{P}_{I}-\mathrm{P}_{R}$, where $\mathrm{P}_{I}$ and $\mathrm{P}_{R}$ are the incident and reflected microwave powers, respectively. The incident and reflected microwave powers $\mathrm{P}_{\mathrm{I}}$ and $\mathrm{P}_{\mathrm{R}}$ were directly measured using directional coupler (MEGA IND. 0G9Y7-66078-704) equipped with HP 478A bolometric heads and HP 432A power meters (Figure 1).

For hydrogen production via hydrocarbon conversion we used the similar waveguide-based nozzleless cylinder-type MPS as in our previous work (Figure 2, [23]). In contrary to the previous work, the processed gaseous hydrocarbons (50-212 $1 \mathrm{~min}^{-1}$ ) were introduced to the plasma not by the central duct of MPS but in the 
form of a swirl. The processed hydrocarbons were introduced to the plasma by the four gas ducts (Figures 3) creating the swirl flow in the discharge cylinder. The swirl concentrated near the quartz cylinder wall and stabilized plasma generation. The swirl held the discharge in the centre of the cylinder and thus protected the cylinder wall from overheating. The inner diameter of the used quartz discharge tube was $26 \mathrm{~mm}$.

The diameter of the copper shielding cylinder is $46 \mathrm{~mm}$, so microwave at frequency of $2.45 \mathrm{GHz}$ cannot be guided along the copper shielding cylinder (operation below the cut-off frequency). This causes lower losses of microwave energy, i.e., the higher microwave power is delivered to the unit volume of the plasma. Moreover, the copper shielding cylinder placed coaxially around the quartz discharge cylinder protected the personnel and instrumentation from the electromagnetic radiation.

Important advantages of the presented waveguide-based nozzleless cylinder-type MPS are: stable operation in various gases (including $\mathrm{CO}_{2}$, air, nitrogen, methane, HFCs) at high flow rates (hundreds $1 \mathrm{~min}^{-1}$, which is similar to other plasma methods operating at high gas flow rate, $[2,8,10])$, easy initiation of the discharge in various gases without any admixture of noble gases, no need for any special cooling system and for sophisticated impedance matching (e.g., no need for a three-stub tuner).

On-line diagnostics of the working gas composition before and after the microwave plasma processing of hydrocarbons was carried out using gas chromatograph (SRI 8610C, sensitivity towards $\mathrm{H}_{2}$ was 0.01\%), Fourier Transform Infrared (FTIR) spectrophotometer (Nicolet 380 with a gas cell of $10 \mathrm{~cm}$ path length, sensitivity towards $\mathrm{CH}_{4}$ and $\mathrm{C}_{2} \mathrm{H}_{2} \mathrm{~F}_{4}$ was $55 \mathrm{ppm}$ and $16 \mathrm{ppm}$, respectively) and hydrogen detector (Crowcon XGard, sensitivity 0.1\%). Gas chromatograph was fixed for the hydrogen measurements using silica gel packed $1 \mathrm{~m}$ column of temperature $60^{\circ} \mathrm{C}$ 
and TCD. Calibration was carried out with hydrogen of purity $99.999 \%$ mixed with nitrogen of $99.99 \%$ purity and injected to the column with 10 port gas sampling valve. Calibration curve was prepared from the hydrogen peak area measured at the TCD for the hydrogen concentrations in the range of $0-100 \%$. FTIR spectrophotometer was calibrated for $\mathrm{CH}_{4}$ and $\mathrm{C}_{2} \mathrm{H}_{2} \mathrm{~F}_{4}$ separately. Mixture of nitrogen of $99.99 \%$ purity and methane of the same purity was flowing through the gas cell when FTIR spectra were recorded. Calibration curve was made from values of peak height at $2885 \mathrm{~cm}^{-1}$. The same procedure was used for $\mathrm{C}_{2} \mathrm{H}_{2} \mathrm{~F}_{4}$ (purity of $98 \%$ ) calibration using the peak area measured from $3048 \mathrm{~cm}^{-1}$ to $2938.6 \mathrm{~cm}^{-1}$.

In order to avoid high pressure drop at the outlet of the plasma device, diagnostics of the gas composition was carried out in the by-pass (Figure 2). Production of hydrogen was calculated from hydrocarbons and their conversion products mass balance.

\section{Results}

\subsection{Production of $\mathrm{H}_{2}$ from $\mathrm{CH}_{4}$}

Diagnostics of the exit gas composition showed that unprocessed methane was found as the only gaseous by-products resulting from methane conversion in microwave plasma. The methane decomposed to hydrogen $\mathrm{H}_{2}$ and carbon (soot). The soot deposit could be easily noticed on the reactor walls. The soot deposition started just after plasma ignition, however not all soot deposited on the reactor walls. Major part of the soot was blown off the reactor by the high gas flow. As a result, the thickness of the 
soot layer deposited on the reactor walls has not exceeded $2 \mathrm{~mm}$ and did not influence the reactor lifetime.

Concentrations of $\mathrm{H}_{2}$ and $\mathrm{CH}_{4}$ in the exit gas depend on the absorbed microwave power. At the power of $1.5 \mathrm{~kW}$ concentrations of hydrogen and methane were $99.88 \%$ and $0.12 \%$, respectively, whereas at the power of $5 \mathrm{~kW}$ they were $99.94 \%$ and $0.06 \%$, respectively. Thus, the total methane conversion degree $\left[\left(\mathrm{CH}_{4}\right)_{\text {converted }} /\left(\mathrm{CH}_{4}\right)_{\text {initial }} \times\right.$ $100 \%$ ] was $99.76-99.88 \%$ (Figure 4), where $\left(\mathrm{CH}_{4}\right)_{\text {initial }}$ is the total mass of $\mathrm{CH}_{4}$, and $\left(\mathrm{CH}_{4}\right)_{\text {converted }}$ is the converted mass of $\mathrm{CH}_{4}$. The selectivity of methane conversion to hydrogen $\left[\mathrm{H}_{2} / 2\left(\mathrm{CH}_{4}\right)_{\text {converted }} \times 100 \%\right]$ was $100 \%$. Such a high selectivity as well as lack of other gaseous by-products and significant production of soot show that reaction of methane pyrolysis was the main path of methane conversion into hydrogen.

The energetic parameters of the hydrogen production via the methane pyrolysis, i.e. the hydrogen mass yield rate (Figure 5a) and energetic hydrogen mass yield (Figure $5 \mathrm{~b}$ ) were up to $866 \mathrm{~g}\left[\mathrm{H}_{2}\right] \mathrm{h}^{-1}$ and $600 \mathrm{~g}\left[\mathrm{H}_{2}\right]$ per $\mathrm{kWh}$ of microwave energy absorbed by the plasma, respectively. The best energetic mass yield of hydrogen corresponds to the absorbed microwave power of $1 \mathrm{~kW}$ (Figure 5b). At higher absorbed microwave power, the energetic mass yield of hydrogen is lower due to the fact, that hydrogen mass yield rate is almost independent on the absorbed microwave power (Figure 5a). At absorbed microwave power of $5 \mathrm{~kW}$, the energetic mass yield of hydrogen reached about $150 \mathrm{~g}\left[\mathrm{H}_{2}\right]$ per $\mathrm{kWh}$ of microwave energy absorbed by the plasma.

In our experiment, the plug efficiency of the microwave magnetron generator was higher than $66 \%$, so taking into account this efficiency, the energetic hydrogen mass yield is up to about $400 \mathrm{~g}\left[\mathrm{H}_{2}\right]$ per $\mathrm{kWh}$ of electrical energy used. 
Comparison of the energetic hydrogen mass yields for different methods in which electric energy is directly used for methane conversion into hydrogen, is given in Table 1.

It must be pointed out that the energetic hydrogen mass yields shown in Table 1 take into account only the electrical energy used in the reforming (in some cases it is not clear either the total electric energy used or absorbed by the plasma is considered). In the plasma methods presented in Table 1, the energy equivalent of methane used in the reforming was not considered.

It is seen from Table 1 that the plasma methods (except the electron beam [13] and dielectric barrier discharge [17]) exhibit higher energetic hydrogen mass yield than the conventional water electrolysis [32]. However, when the energy equivalent of methane used in the conversion is taken into account, the energetic hydrogen mass yields for the plasmatron with catalyst [2] and our method, which exhibit the highest yields, are comparable with that of the conventional water electrolysis.

Considering both the cost of methane and the total energy consumption (including losses in power supplies), nowadays, among the hydrogen production methods, it seems that the conventional steam reforming of methane [33] ensures the lowest cost of hydrogen production. However, the conventional steam reforming of methane is a large volume hydrogen production method. When the distributed hydrogen production method are considered, the microwave plasma method presented in this paper seems to be attractive.

\subsection{Production of $\mathrm{H}_{2}$ from $\mathrm{C}_{2} \mathrm{H}_{2} \mathrm{~F}_{4}$ (HFC-134a)}

The on-line analysis of the exit gas composition using FTIR spectrophotometer 
showed that unprocessed $\mathrm{C}_{2} \mathrm{H}_{2} \mathrm{~F}_{4}$ was found as the only gaseous compound detectable by FTIR after the conversion of $\mathrm{C}_{2} \mathrm{H}_{2} \mathrm{~F}_{4}$ in the microwave plasma However, since the $\mathrm{C}_{2} \mathrm{H}_{2} \mathrm{~F}_{4}$ was decomposed and soot (carbon black) was produced as a solid by-product, it is obvious that other gaseous by-products, i.e. $\mathrm{F}_{2}$ and $\mathrm{H}_{2}$, which are not detectable by FTIR, also had to be in the exit gas. We monitored the presence of $\mathrm{H}_{2}$ in the exit gas using the hydrogen detector, whereas $F_{2}$ in the exit gas was detected (qualitative detection), observing changes of the colour of a paper wetted with potassium iodide and starch solution. The soot deposits could be easily noticed on the reactor walls.

Two series (series 1 and series 2) of measurements were carried out. In series 1 the $\mathrm{C}_{2} \mathrm{H}_{2} \mathrm{~F}_{4}$ treatment was performed at constant flow rate $\left(50\right.$ and $\left.971 \mathrm{~min}^{-1}\right)$ for various absorbed microwave powers. In series 2 the $\mathrm{C}_{2} \mathrm{H}_{2} \mathrm{~F}_{4}$ treatment was carried out for selected values of $\mathrm{C}_{2} \mathrm{H}_{2} \mathrm{~F}_{4}$ flow rate and absorbed microwave power. The conversion degree of $\mathrm{C}_{2} \mathrm{H}_{2} \mathrm{~F}_{4}$ after plasma treatment as a function of absorbed microwave power is shown in figure 6. At a power of $0.6-3 \mathrm{~kW}$ and $\mathrm{C}_{2} \mathrm{H}_{2} \mathrm{~F}_{4}$ flow rate of $50-2121 \mathrm{~min}^{-1}$, total $\mathrm{C}_{2} \mathrm{H}_{2} \mathrm{~F}_{4}$ conversion degree $\left[\left(\mathrm{C}_{2} \mathrm{H}_{2} \mathrm{~F}_{4}\right)_{\text {converted }} /\left(\mathrm{C}_{2} \mathrm{H}_{2} \mathrm{~F}_{4}\right)_{\text {initial }} \times 100 \%\right]$ was $63.3-$ $84.1 \%$.

The selectivity of $\mathrm{C}_{2} \mathrm{H}_{2} \mathrm{~F}_{4}$ conversion to hydrogen $\left[\mathrm{H}_{2} /\left(\mathrm{C}_{2} \mathrm{H}_{2} \mathrm{~F}_{4}\right)_{\text {converted }} \times 100 \%\right]$ was $99.99 \%$ in all cases. Such a high selectivity as well as lack of other gaseous hydrogen containing by-products and significant production of soot show that thermal dissociation of $\mathrm{C}_{2} \mathrm{H}_{2} \mathrm{~F}_{4}$ was the main path of $\mathrm{C}_{2} \mathrm{H}_{2} \mathrm{~F}_{4}$ conversion into the hydrogen and fluorine.

The $\mathrm{H}_{2}$ mass yield rate and energetic mass yield calculated from the mass balance, are shown in figures $7 \mathrm{a}$ and $7 \mathrm{~b}$. The mass yield rates of products reached $0.7 \mathrm{~kg}\left[\mathrm{H}_{2}\right] \mathrm{h}^{-1}$ for $\mathrm{H}_{2}$. The mass yield rate of $\mathrm{H}_{2}$ is also almost independent of the absorbed microwave 
power $\mathrm{P}_{\mathrm{A}}$ at constant $\mathrm{C}_{2} \mathrm{H}_{2} \mathrm{~F}_{4}$ flow rate. The reason of such behaviour is the constant gas temperature in the plasma versus the microwave power delivered to the discharge at constant $\mathrm{C}_{2} \mathrm{H}_{2} \mathrm{~F}_{4}$ flow rate. The best energetic mass yield of hydrogen reached $670 \mathrm{~g}\left[\mathrm{H}_{2}\right]$ per kWh of microwave energy absorbed by the plasma (Figure $7 b$ ). This value corresponds to the $\mathrm{C}_{2} \mathrm{H}_{2} \mathrm{~F}_{4}$ flow rate of $97 \mathrm{~min}^{-1}$ and absorbed microwave power of $0.6 \mathrm{~kW}$. At higher absorbed microwave power, the energetic mass yield of hydrogen is lower due to the fact, that conversion degree of $\mathrm{C}_{2} \mathrm{H}_{2} \mathrm{~F}_{4}$ is almost independent on the absorbed microwave power (Figure 6).

The energetic parameters of tetrafluoroethane destruction obtained in the present experiment are superior to those when other plasma methods (e.g. corona [34], barrier discharges [35, 36], gliding [37] and arc [38, 39, 40] discharges, low-power [41-43] or moderated-power [27] microwave torch discharges) were employed for destruction of HFCs. Among the other plasma methods, the best energetic parameters $\left(\mathrm{C}_{2} \mathrm{H}_{2} \mathrm{~F}_{4}\right.$ destruction degree, $\mathrm{C}_{2} \mathrm{H}_{2} \mathrm{~F}_{4}$ mass yield rate and $\mathrm{C}_{2} \mathrm{H}_{2} \mathrm{~F}_{4}$ energetic mass yield) of $\mathrm{C}_{2} \mathrm{H}_{2} \mathrm{~F}_{4}$ destruction were achieved by Watanabe et al. [39] and Ohno et al. [40] using DC arc plasma torches. There destruction degree, mass yield rate and energetic mass yield of $\mathrm{C}_{2} \mathrm{H}_{2} \mathrm{~F}_{4}$ were up to $100 \%, 2 \mathrm{~kg}\left[\mathrm{C}_{2} \mathrm{H}_{2} \mathrm{~F}_{4}\right] \mathrm{h}^{-1}$ and $0.7 \mathrm{~kg}\left[\mathrm{C}_{2} \mathrm{H}_{2} \mathrm{~F}_{4}\right] \mathrm{kWh}^{-1}$, respectively. Our method ensured the best mass yield rate and energetic mass yield. Due to the absence of oxygen/air in the initial gas in our method, resulting in the lack of oxidation reactions, the destruction degree $(84 \%)$ of the processed tetrafluoroethane was lower than in our previous investigations and when using DC arc plasma torches. 


\section{Conclusions}

The results of this investigations show that hydrogen may be produced by pyrolysis of both methane and tetrafluoroethane.

When methane flow rate was $87.5 \mathrm{l} / \mathrm{min}$, the total methane conversion degree was 99.76-99.88\%, depending on microwave power delivered. When methane flow rate was doubled then only half of $\mathrm{CH}_{4}$ was converted. The energetic parameters of the hydrogen production via methane conversion, i.e. the $\mathrm{H}_{2}$ mass yield rate and energetic $\mathrm{H}_{2}$ mass yield were up to $866 \mathrm{~g}\left[\mathrm{H}_{2}\right] \mathrm{h}^{-1}$ and $640 \mathrm{~g}\left[\mathrm{H}_{2}\right]$ per $\mathrm{kWh}$ of microwave energy absorbed by the plasma.

When $\mathrm{C}_{2} \mathrm{H}_{2} \mathrm{~F}_{4}$ was used as a source of $\mathrm{H}_{2}$, the total tetrafluoroethane conversion degree was $63.3-84.1 \%$, depending on tetrafluoroethane flow rate. In this case, the energetic parameters of the $\mathrm{H}_{2}$ production, i.e. the $\mathrm{H}_{2}$ mass yield rate and energetic $\mathrm{H}_{2}$ mass yield were up to $700 \mathrm{~g}\left[\mathrm{H}_{2}\right] / \mathrm{h}$ and $670 \mathrm{~g}\left[\mathrm{H}_{2}\right]$ per $\mathrm{kWh}$ of microwave energy absorbed by the plasma, respectively.

The conversion degree of both hydrocarbons and $\mathrm{H}_{2}$ mass yield rate are almost independent on the absorbed microwave power. When increasing the microwave power delivered to the discharge, the electron density and electron temperature increase, but the gas temperature is constant. This confirms that thermal pyrolysis is the main path of hydrocarbon conversion.

The proposed atmospheric pressure microwave plasma system for hydrogen production via hydrocarbons pyrolysis is expected to be of low cost and effective, and thus promising for applications in the distributed hydrogen production.

The absence of oxygen compounds as by-products in the off-gas is important 
advantage of the presented method.

\section{Acknowledgements}

This research was supported by the Ministry of Science and Higher Education (MNiSW) under the programmes NR14-0091-10 and PB 2595/B/T02/2008/35.

\section{References:}

[1] G. Petitpas, J.-D. Rollier, A. Darmon, J. Gonzalez-Aguilar, R. Metkemeijer, L. Fulcheri, Int. J. Hydrogen Energy, 32, issue 14, (2007) 2848-2867.

[2] L. Bromberg, D.R. Cohn, A. Rabinovich, N. Alexeev, A. Samokhin, R. Ramprasad, S. Tamhankar, Int. J. Hydrogen Energy, 25 (2000) 1157-1161.

[3] L. Bromberg, D.R. Cohn, A. Rabinovich, N. Alexeev, Int. J. Hydrogen Energy, 24 (1999) 1131-1137.

[4] T. Bergene, Int. J. Hydrogen Energy, 21 (1996) 189-194.

[5] A. Fujishima, X. Zhanga, D.A. Tryk, Int. J. Hydrogen Energy, 32 (2007) 26642672.

[6] F.R. Hawkes, R. Dinsdale, D.L. Hawkes, I. Hussy, Int. J. Hydrogen Energy, 27 (2002) 1339-1347.

[7] Y. Asada, J. Miyake, J. Biosci. Bioeng., 88 (1999) 1-6.

[8] J.M. Cormier, I. Rusu, J. Phys. D: Appl. Phys., 34 (2001) 2798-2803.

[9] N. Reveau, M. Nikravech, O. Martinie, P. Lefaucheux, J.M. Cormier, in Proc. HAKONE VII, Greifswald, Germany, 2000, pp. 252-256. 
[10] A. Czernichowski, M. Czernichowski, P. Czernichowski, in Proc. $16^{\text {th }}$ Int. Symp. on Plasma Chemistry, Taormina, Italy, 2003, pp. 578.

[11] H. Sekiguchi, Y. Mori, Thin Solid Films, 435 (2003) 44-48.

[12] H. Sekiguchi, S.Nakanishi, K.Fukuda, H.Inagaki, in Proc. $16^{\text {th }}$ Int. Symp. on Plasma Chemistry, Taormina, Italy, 2003, pp. 598.

[13] T. Kappes, W. Schiene, T. Hammer, in Proc. $8^{\text {th }}$ Int. Symp. on High Pressure Low Temperature Plasma Chemistry, Puhajarve, Estonia, 2002, pp. 196-200.

[14] H. Kabashima, H. Einaga, S. Futamura, IEEE Trans. Ind. Appl., 39 (2003) 340345.

[15] S. Futamura, H. Kabashima, L. Ma, in Proc. $4^{\text {th }}$ Int. Symp. on Non-thermal Plasma Technology for Pollution Control and Sustainable Energy Development, Panama City Beach, Florida, USA, 2004, pp. 211-215.

[16] B. Pietruszka, K. Anklam, M. Heintze, Appl. Catal. A: General, 261 (2004) 1924.

[17] M. Heintze, B. Pietruszka, Catal. Today, 89 (2004) 21-25.

[18] B. Pietruszka, K. Anklam, M. Heintze, in $16^{\text {th }}$ Int. Symp. on Plasma Chemistry, Taormina, Italy, 2003, p. 582.

[19] O. Mutaf-Yardimci, A.V. Saveliev, A.A. Fridman, L.A. Kennedy, Int. J. Hydrogen Energy, 23 (1998) 1109-1111.

[20] J.S. Chang, Y. Uchida, M. Ara, J.T. Kim, K. Urashima, J.F. Kelly, M. Stanciulescu, R. Burisch, J.P. Charland, in Proc. $4^{\text {th }}$ Int. Symp. on Non-thermal Plasma Technology for Pollution Control and Sustainable Energy Development, Panama City Beach, Florida, USA, 2004, pp. 216-220.

[21] T. Kappes, T. Hammer, in Proc. $4^{\text {th }}$ Int. Symp. on Non-thermal Plasma 
Technology for Pollution Control and Sustainable Energy Development, Panama City Beach, Florida, USA, 2004, pp. 206-210.

[22] M. Deminsky, V. Jivotov, B. Potapkin, V. Rusanov, Pure and Applied Chemistry, 74 (2002) 413-418.

[23] M. Jasiński, M. Dors, J. Mizeraczyk, Journal of Power Sources, 181, issue 1, (2008) 41-45.

[24] M. Moisan, G. Sauve, Z. Zakrzewski, J. Hubert, Plasma Sources Sci. Technol., 3 (1994) 584.

[25] M. Moisan, Z. Zakrzewski, J.C. Rostaining. Plasma Sources Sci. Technol., 10 (2001) 387.

[26] M. Jasiński, J. Mizeraczyk, Z. Zakrzewski, Czechoslovak Journal of Physics, 52 (2002) 421-426.

[27] M. Jasiński, J. Mizeraczyk, Z. Zakrzewski, T. Ohkubo, J.S. Chang, J. Phys. D: Appl. Phys., 35 (2002) 2274.

[28] M. Jasiński, J. Mizeraczyk, Z. Zakrzewski, Journal of Advanced Oxidation Technologies, 7 (2004) 51-58.

[29] J. Mizeraczyk, M. Jasiński, Z. Zakrzewski, Plasma Phys. Control. Fusion, 47 (2005) 589-602.

[30] K.M. Green, M.C. Borras, P.P. Woskow, G.J. Flores, K. Hadidi, P. Thomas, IEEE Trans. Plasma Sci., 29 (2001) 399.

[31] H.S. Uhm, Y.C. Hong, D.H. Shin, Plasma Sources Sci. Technol., 15 (2006) S26.

[32] http://www.loim.vrn.ru/index.php?m=63\&page=58\&nm=74\&p=.2.3.56.64.70. 71.72.73. 74 .

[33] P.L. Spath, M.K. Mann, National Renewable Energy Laboratory Technical 
Report, 2001, NREL/TP-570-27637.

[34] J.D. Skalny, V. Sobek, P. Lukac, NATO ASI Series, 1993, G34A, 151-165

[35] J.H. Oh, Y.S. Mok, S.B. Lee, M.S. Chang, Journal of the Korean Physical Society, 54 (4) (2009) 1539-1546

[36] Y.S. Mok, S.B. Lee, M.S. Chang, IEEE Transactions on Plasma Science, 37 (3) (2009) 449-455

[37] A. Opalska, T. Opalińska, J. Polaczek, P. Ochman, Int. Symp. HAKONE VIII, 2002, 191-195

[38] A. Rusowicz, Chłodnictwo and Klimatyzacja, 11-12 (2000) 26-8 (in Polish)

[39] T. Watanabe, T. Tsuru, Thin Solid Films, 516 (13) (2008) 4391-4396

[40] M. Ohno, Y. Ozawa, T. Ono, International Journal of Plasma Environmental Science \& Technology, 1 (2) (2007) 159-165

[41] M. Jasiński, P. Szczucki, M. Dors, J. Mizeraczyk, M. Lubański, Z. Zakrzewski, Czech. J. Phys. 50 (2000) 285-8.

[42] Jasiński M, Szczucki P, Mizeraczyk J, Lubański M and Zakrzewski Z 2000 Trans. Institute of Fluid-Flow Machinery 107 55-63

[43] Jasiński M, Mizeraczyk J, Czylkowski D and Zakrzewski Z 2001 Trans. Institute of Fluid-Flow Machinery 109 13-22 


\section{Table and figure captions}

Table 1. Comparison of the energetic hydrogen mass yields for different methods in which electric energy is directly used for methane conversion into hydrogen.

Figure 1. Photo of the experimental setup with the waveguide-based nozzleless cylinder-type MPS.

Figure 2. Sketch of the waveguide-based nozzleless cylinder-type MPS.

Figure 3. Bottom view on the plasma (a) with a swirl flow and four ducts creating swirl flow (b).

Figure 4. Conversion degree of methane resulting from methane conversion using the waveguide-based nozzleless cylinder-type MPS.

Figure $5 \mathrm{a} . \mathrm{H}_{2}$ mass yield rate as a function of absorbed microwave power. $\mathrm{CH}_{4}$ flow rate: $50-2121 \min ^{-1} . \mathrm{H}_{2}$ mass yield rate resulted from the $\mathrm{H}_{2}$ concentration measurement.

Figure 5b.Energetic mass yield rate of $\mathrm{H}_{2}$ as a function of absorbed microwave power. $\mathrm{CH}_{4}$ flow rate: $50-2121 \mathrm{~min}^{-1}$.

Figure 6. Conversion degree of tetrafluoroethane as a function of absorbed microwave power.

Figure $7 \mathrm{a} . \mathrm{H}_{2}$ mass yield rate as a function of absorbed microwave power. HFC-134a flow rate: $50-2121 \mathrm{~min}^{-1} \cdot \mathrm{H}_{2}$ mass yield rate resulted from the $\mathrm{H}_{2}$ concentration measurement.

Figure $7 \mathrm{~b}$.Energetic mass yield rate of $\mathrm{H}_{2}$ as a function of absorbed microwave power. HFC-134a flow rate: $50-2121 \mathrm{~min}^{-1}$. 


\begin{tabular}{|c|c|c|}
\hline $\begin{array}{c}\text { Hydrogen production } \\
\text { method }\end{array}$ & Initial composition & $\begin{array}{c}\text { Energetic mass yield } \\
{\left[\mathrm{g}\left[\mathrm{H}_{2}\right] \mathrm{kWh}^{-1}\right]}\end{array}$ \\
\hline \multicolumn{3}{|c|}{ CONVENTIONAL METHOD } \\
\hline $\begin{array}{c}\text { Water electrolysis } \\
\text { [32] }\end{array}$ & $\mathrm{H}_{2} \mathrm{O}$ & $21^{*}$ \\
\hline \multicolumn{3}{|c|}{ PLASMA METHODS } \\
\hline $\begin{array}{c}\text { Waveguide-based } \\
\text { cylinder-type MPS } \\
\text { (our result) }\end{array}$ & $\mathrm{CH}_{4}$ & $600\left(400^{*}\right)\left(16.8^{* * *}\right)$ \\
\hline $\begin{array}{c}\text { Electron beam } \\
{[13]}\end{array}$ & $\mathrm{CH}_{4}+\mathrm{H}_{2} \mathrm{O}$ & 3.6 \\
\hline $\begin{array}{c}\text { Dielectric barrier } \\
\text { discharge } \\
{[17]}\end{array}$ & $\mathrm{CH}_{4}+$ air & 6.7 \\
\hline $\begin{array}{c}\text { Gliding arc } \\
\text { [8] }\end{array}$ & $\mathrm{CH}_{4}+\mathrm{H}_{2} \mathrm{O}+$ air & 40 \\
\hline $\begin{array}{c}\text { Plasmatron with } \\
\text { catalyst } \\
{[2]}\end{array}$ & $\mathrm{CH}_{4}+\mathrm{H}_{2} \mathrm{O}+$ air & 225 \\
\hline $\begin{array}{c}\text { Waveguide-based } \\
\text { cylinder-type MPS } \\
{[23]}\end{array}$ & $\mathrm{CH}_{4}+\mathrm{N}_{2}$ & $74\left(50^{*}\right)\left(13.2^{* *}\right)$ \\
\hline
\end{tabular}

* at the total electric energy used

** including energy equivalent of methane 
Microwave Directional coupler Magnetron head power with $(2.45 \mathrm{GHz}, 6 \mathrm{~kW})$ meters bolometric heads

MPS with external copper cylindrical electrode

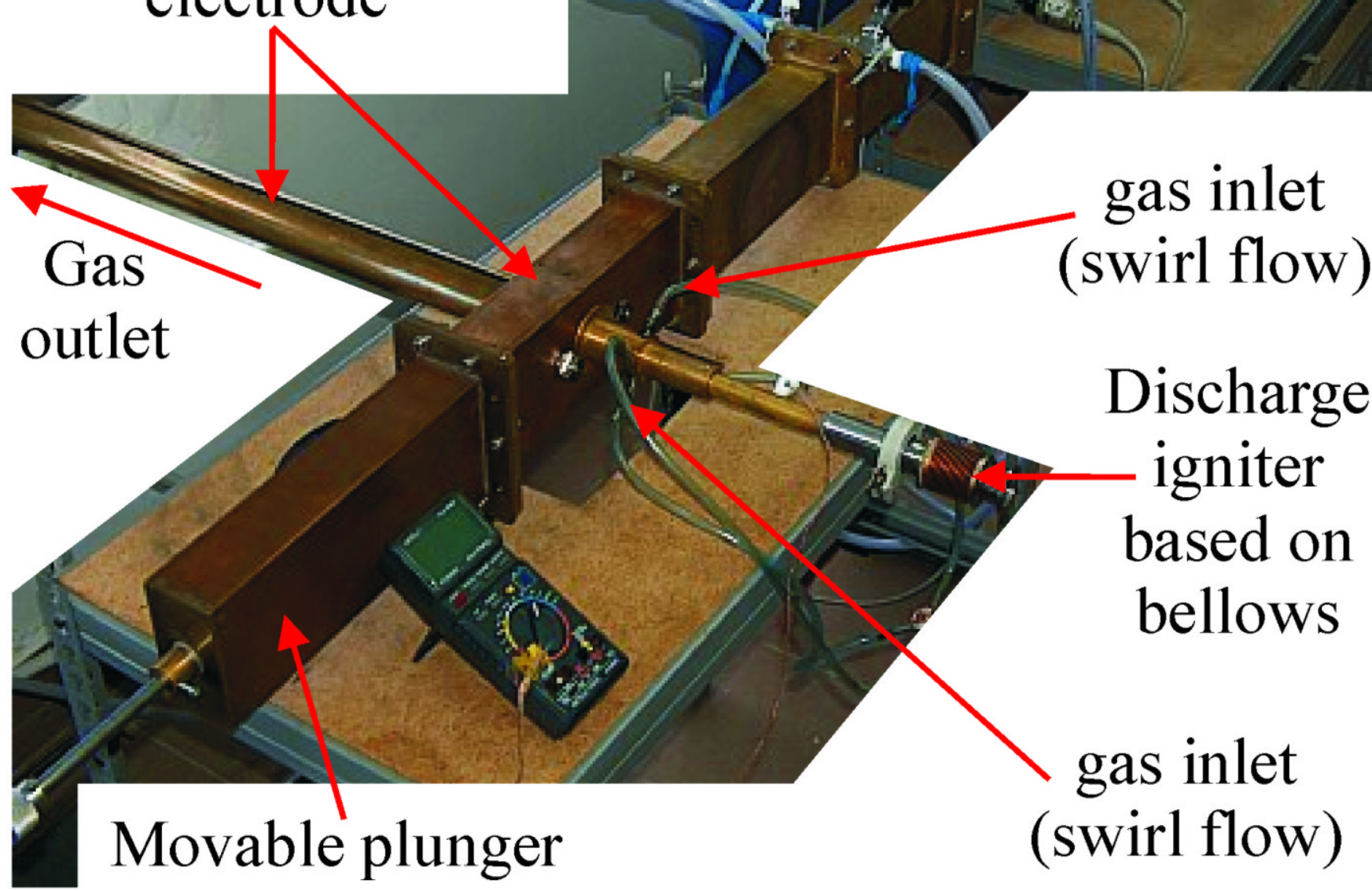

Figure 1 (Fig1_Jasinski.tif) 


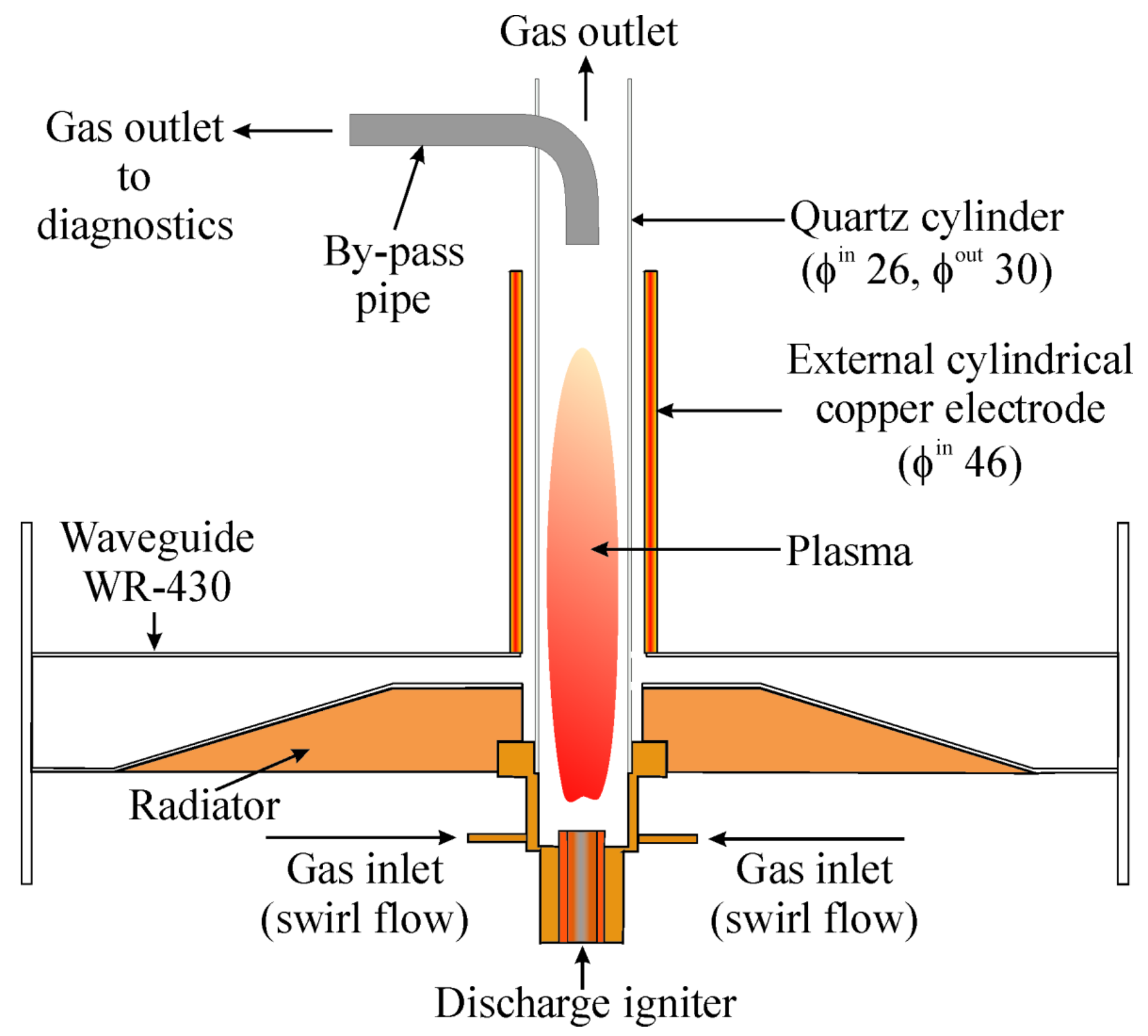

Figure 2 (Fig2_Jasinski_revised.tif) 


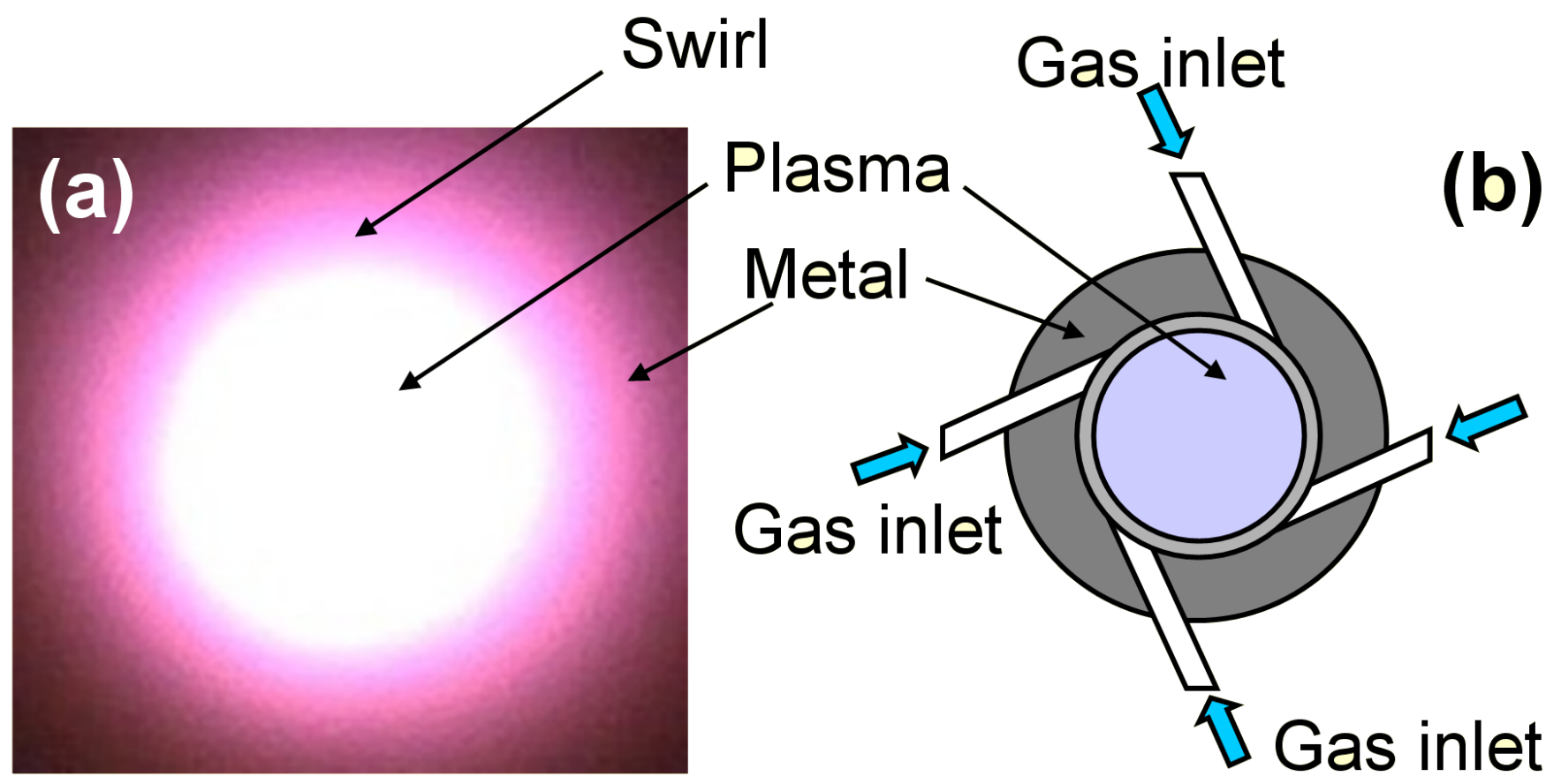

Figure 3 (Fig3_Jasinski.tif) 
Nozzleless MPS with $\mathrm{CH}_{4}$ swirl

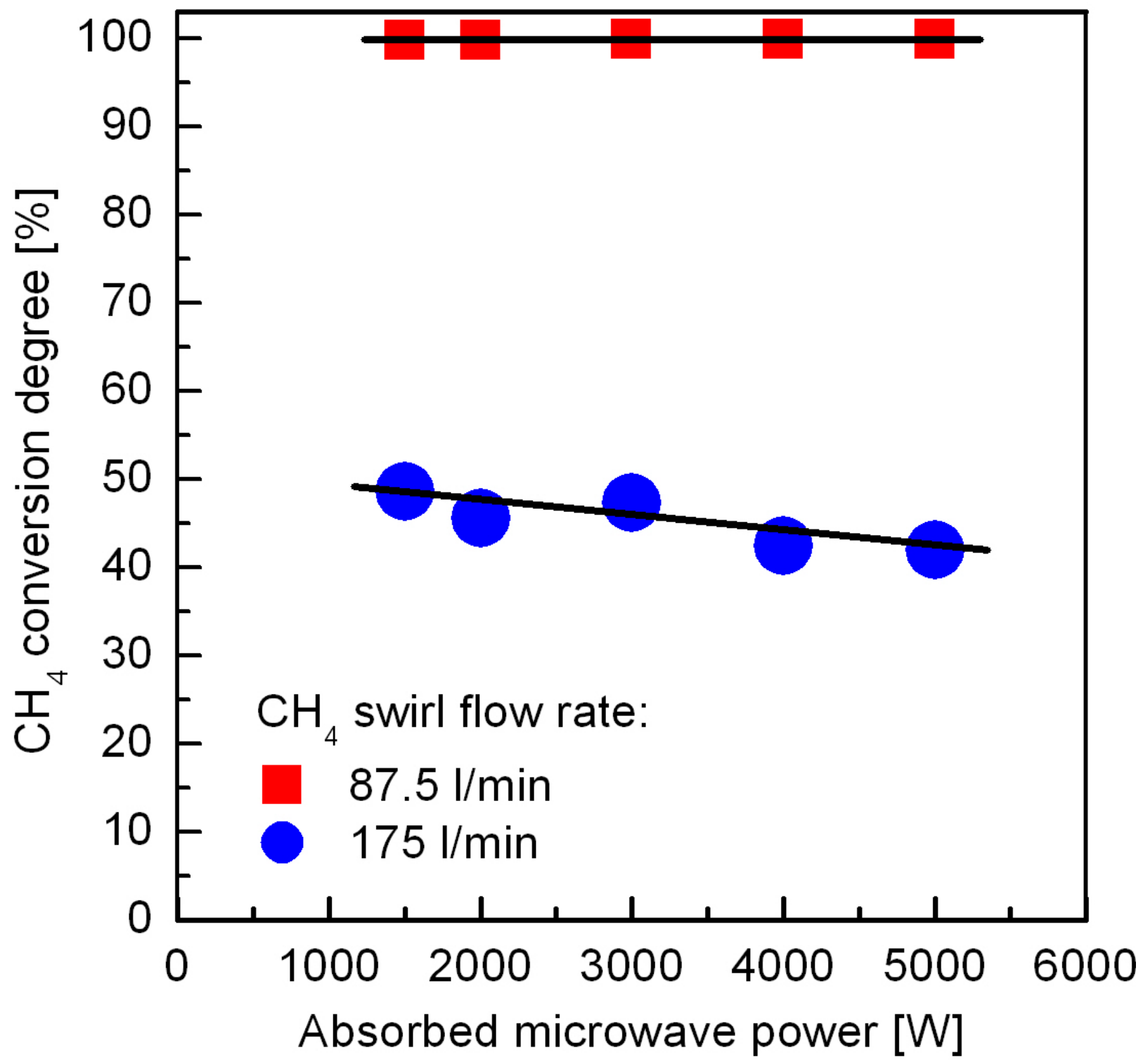

Figure 4 (Fig4_Jasinski.tif) 


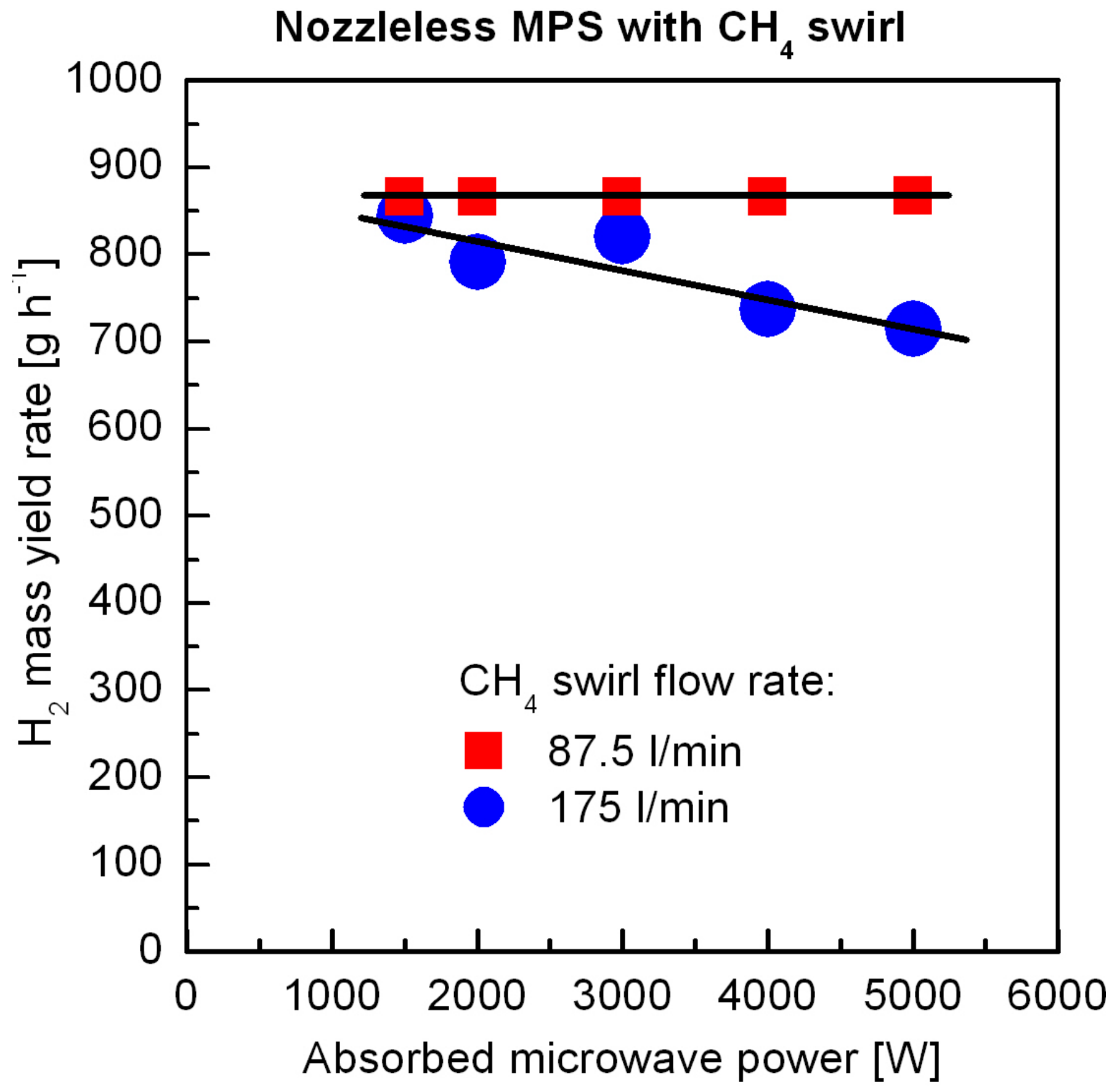

Figure 5a (Fig5a_Jasinski.tif) 


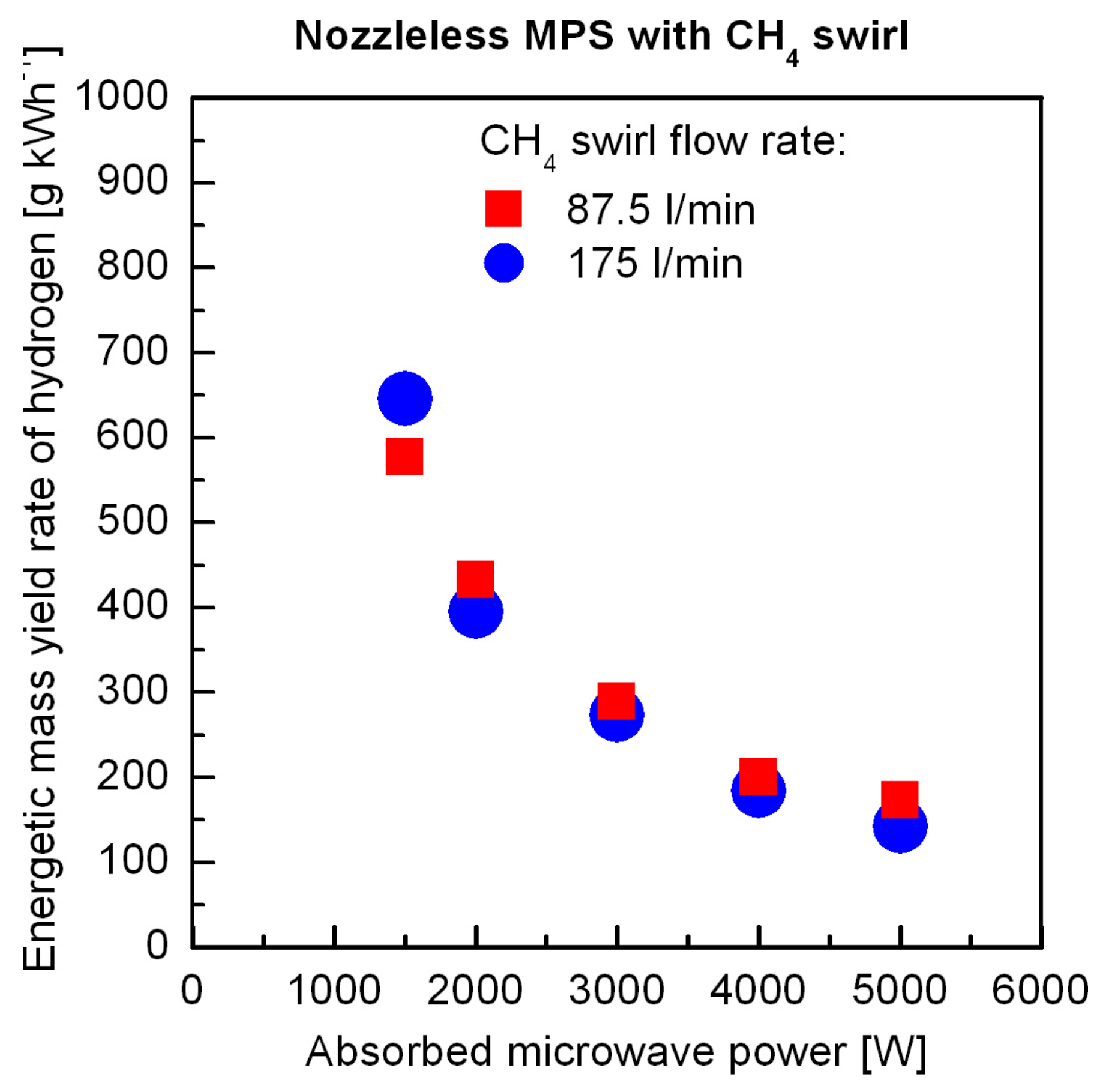

Figure 5b (Fig5b_Jasinski.tif) 


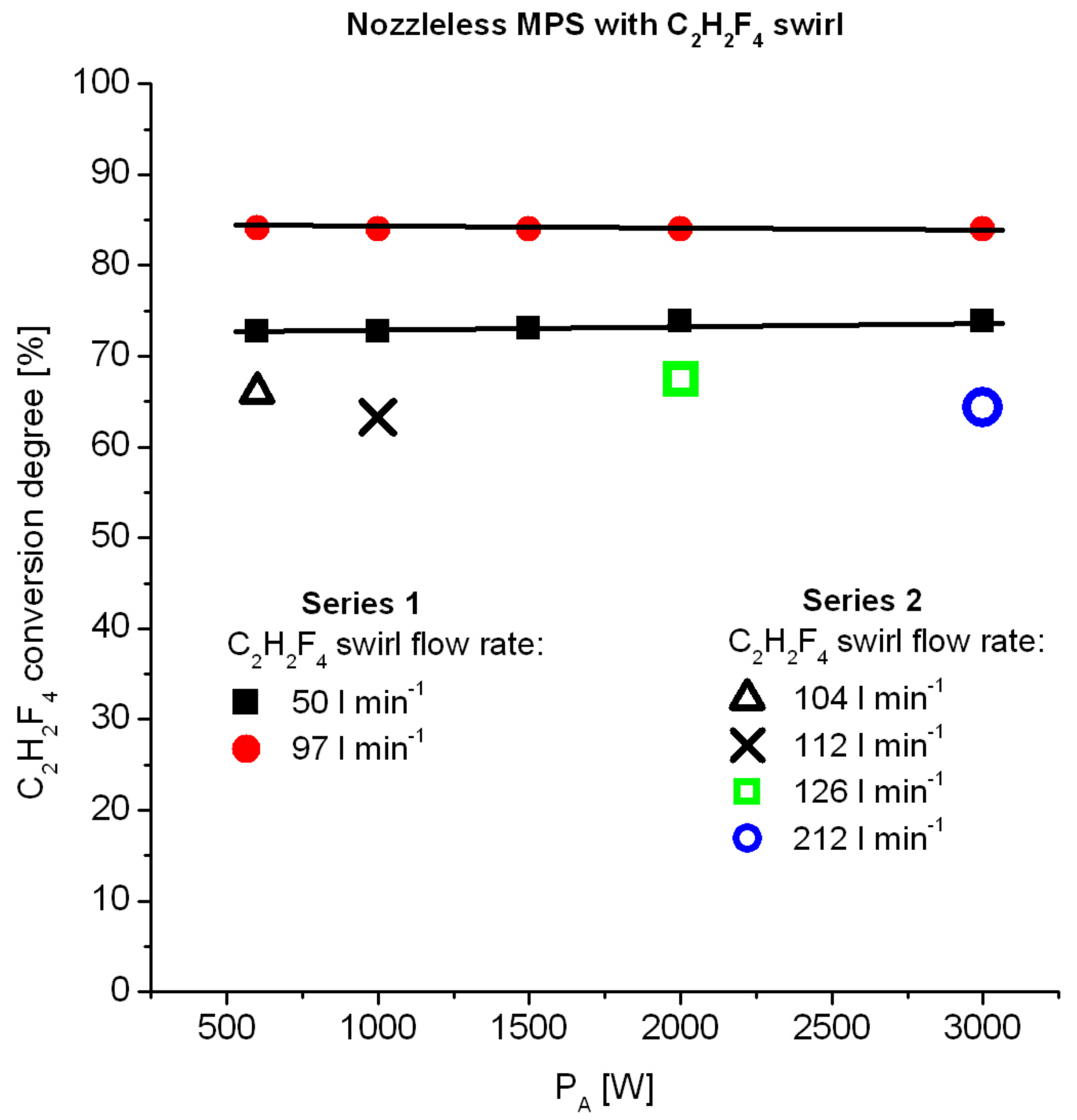

Figure 6 (Fig6_Jasinski.tif) 
Nozzleless MPS with $\mathrm{C}_{2} \mathrm{H}_{2} \mathrm{~F}_{4}$ swirl

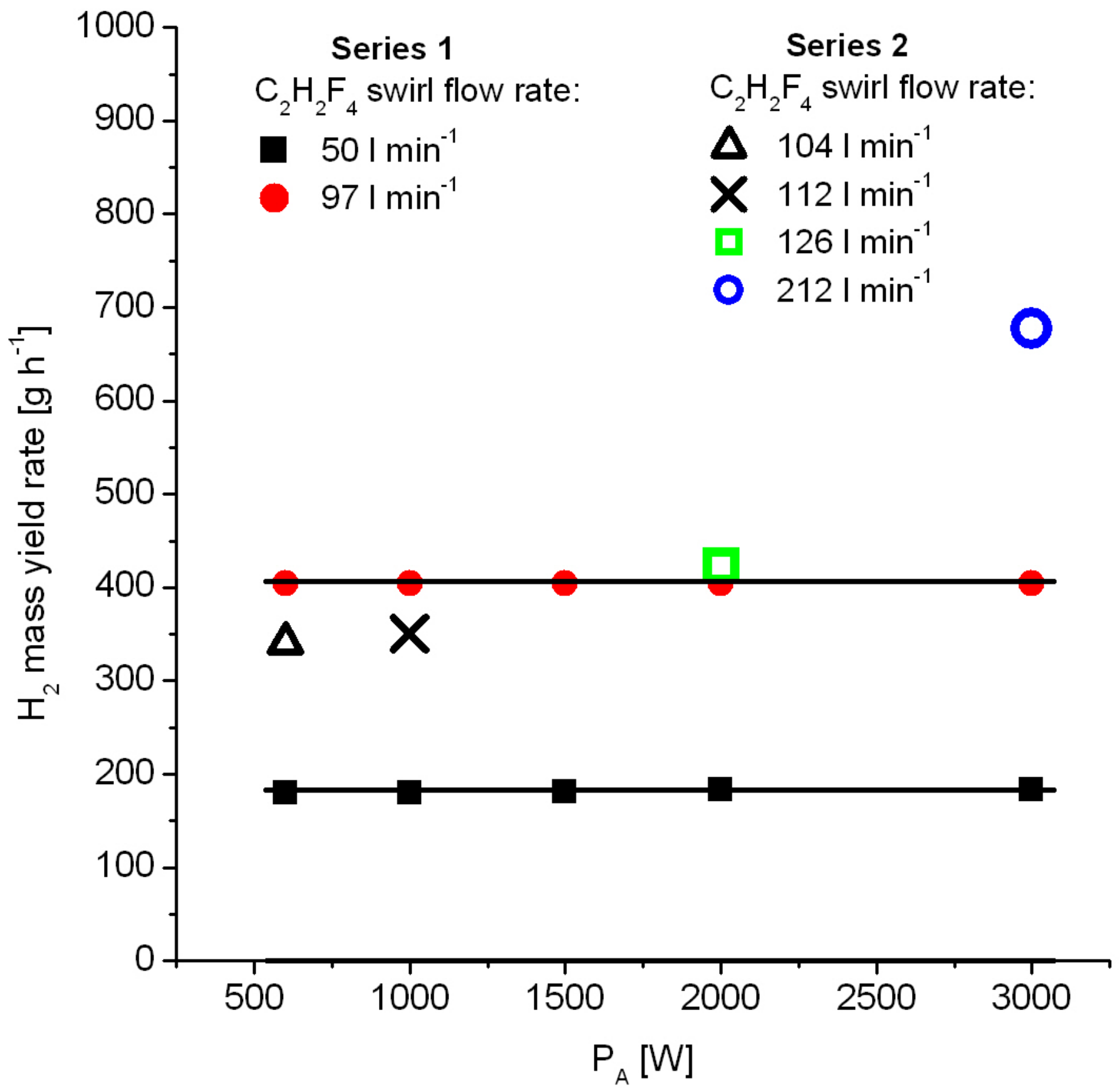

Figure 7a (Fig7a_Jasinski.tif) 
Nozzleless MPS with $\mathrm{C}_{2} \mathrm{H}_{2} \mathrm{~F}_{4}$ swirl

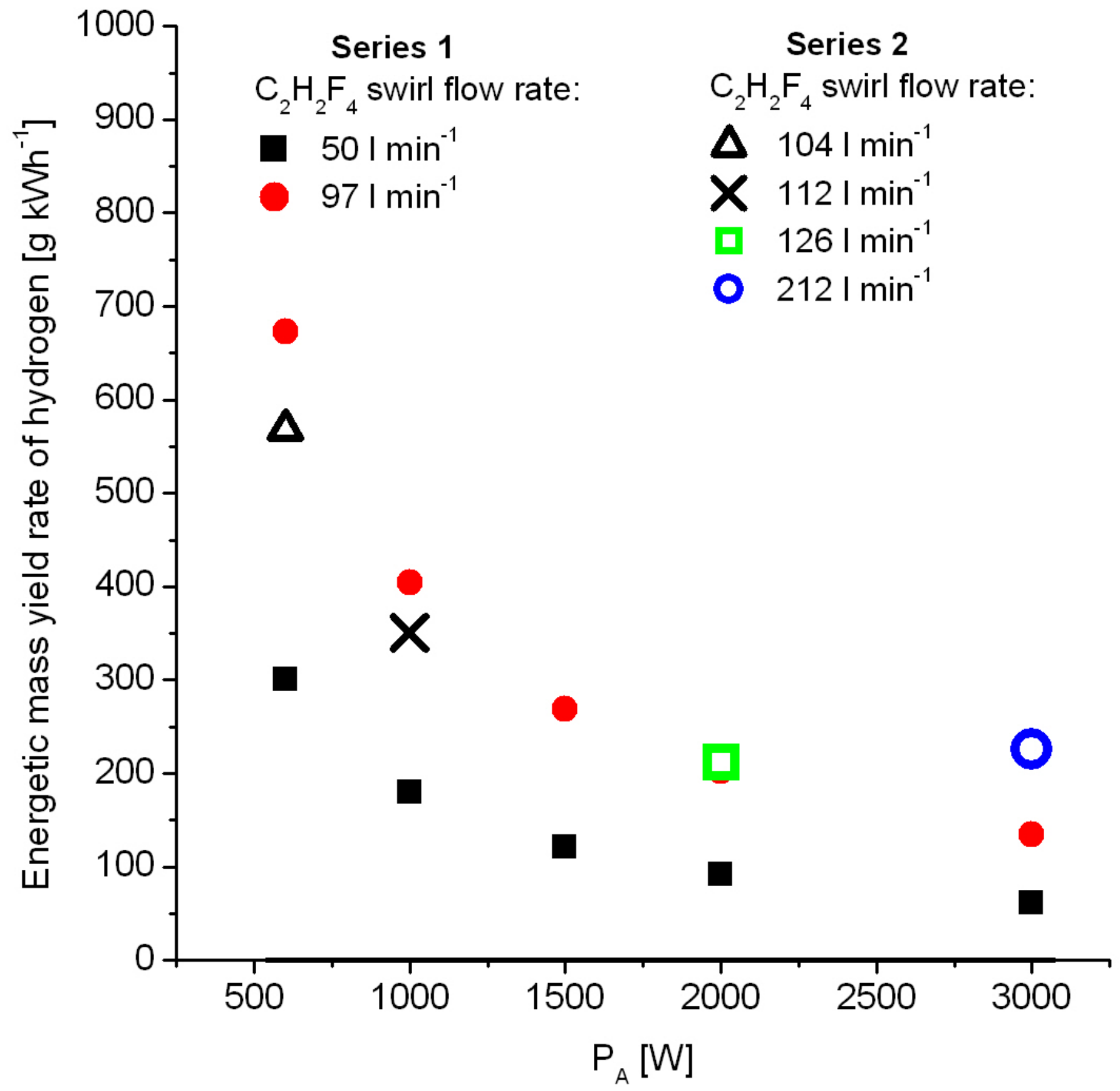

Figure 7b (Fig7b_Jasinski.tif) 